Jurnal IImu Komunikasi UHO : Jurnal Penelitian Kajian IImu Komunikasi dan Informasi.

Volume 7, No. 1, Januari 2022, hlm 47-62

\title{
PENGGUNAAN BAHASA DAERAH SEBAGAI STRATEGI PENYULUHAN PADA PERWAKILAN BKKBN PROVINSI SULAWESI TENGGARA
}

\author{
Dian Eka Sari ${ }^{1}$, La Tarifu ${ }^{2}$, M. Najib Husain ${ }^{3}$ \\ 1,2,3 Pasca Sarjana Universitas Halu Oleo, Kendari \\ dianeka300986@gmail.com
}

\begin{abstract}
ABSTRAK
Tujuan penelitian ini adalah untuk mengetahui dan menganalisis penggunaan bahasa daerah sebagai strategi penyuluhan program keluarga berencana pada perwakilan Badan Kependudukan dan keluarga Berencana Nasional Provinsi Sulawesi Tenggara dan untuk mengetahui dan menganalisis strategi penyuluhan program keluarga berencana pada perwakilan Badan Kependudukan dan Keluarga Berencana Nasional Provinsi Sulawesi Tenggara. Dalam penelitian ini yang menjadi informan 9 orang. Penentuan informan menggunakan tehnik purposive sampling. Metode analisis menggunakan model analisis interaktif. Hasil penelitian menunjukkan bahwa Pemanfaatan bahasa daerah melalui poster dan media sosial sebagai sebuah strategi komunikasi yang digunakan oleh Penyuluh Keluarga Berencana dengan menggunakan pisau analitis dari asumsi teori difusi inovasi sebagai indikatornya maka ditemukan beberapa hal; pertama, pada tahap pengetahuan penggunaan bahasa daerah untuk menanamkan pemahaman pada akseptor maupun calon akseptor tentang program utama dari BKKBN. Kedua, untuk tahap persuasi bagaimana para PKB menujukan sikap yang perubahan terhadap sebuah inovasi, pada tahap ini masyarakat butuh aksi yang lebih dari sekedar poster saja. Makanya strategi dari PKB mengharuskan mereka untuk turun langsung ke masyarakat untuk memberikan pemahaman.
\end{abstract}

Kata Kunci : Bahasa Daerah, Strategi Penyuluhan dan Keluarga Berencana. 
Jurnal IImu Komunikasi UHO : Jurnal Penelitian Kajian IImu Komunikasi dan Informasi.

Volume 7, No. 1, Januari 2022, hlm 47-62

\title{
USING REGIONAL LANGUAGES AS AN EXTENSION STRATEGY ON BKKBN REPRESENTATIVES SOUTHEAST SULAWESI PROVINCE
}

\begin{abstract}
The purpose of this study was to determine and analyze the use of regional languages as a strategy for counseling family planning programs at representatives of the National Population and Family Planning Agency of Southeast Sulawesi Province and to identify and analyze family planning program extension strategies to representatives of the National Population and Family Planning Board of Southeast Sulawesi Province. In this study, 9 people became informants. Determination of informants using purposive sampling technique. The analysis method uses an interactive analysis model. The results showed that the use of local languages through posters and social media as a communication strategy used by Family Planning Extension Officers using an analytical knife from the assumption of the diffusion of innovation theory as an indicator, several things were found; first, at the knowledge stage of using local languages to instill understanding in acceptors and prospective acceptors about the main program of the BKKBN. Second, for the persuasion stage, how the PKB shows a change in attitude towards an innovation, at this stage the community needs action that is more than just a poster. That's why the PKB strategy requires them to go directly to the community to provide understanding.
\end{abstract}

Keywords: Regional Language, Extension Strategy and Family Planning 
Jurnal IImu Komunikasi UHO : Jurnal Penelitian Kajian IImu Komunikasi dan Informasi.

Volume 7, No. 1, Januari 2022, hlm 47-62

\section{PENDAHULUAN}

Penyuluh Keluarga Berencana (PKB) yang menjadi ujung tombak di lapangan berperan penting menjabarkan visi dan misi program KB. Program KB yang beragam harus diterjemahkan dengan baik di lapangan dan masyarakat sebagai pihak pengguna program dapat menikmatinya. Tugas utama PKB adalah mempertahankan pencapaian angka kesertaan KB yang tinggi dan mengendalikan angka kelahiran penduduk di wilayah binaannya. Peran PKB memotivasi dan membina akseptor KB dan menjaga hubungan komunikasi dengan keluarga binaan. PKB menjadi ujung tombak yang langsung berhadapan dengan akseptor KB terkait berbagai permasalahan dan isu di masyarakat. Keberhasilan ini tergantung kepiawaian PKB meyakinkan calon akseptor KB untuk mengadopsi metode ber-KB.

PKB dalam melakukan penyuluhan penggunaan $\mathrm{KB}$, saat ini terkendala dengan adanya Covid-19 (coronavirus disease 2019), sejak ditetapkannya aturan kebiasaan baru dengan menghindari kerumunan dan jaga jarak maka strategi penyuluhan yang dilakukan oleh PKB semakin variatif dan berbagai strategi. PKB dalam melakasakan tugasnya tentu saja harus memiliki strategi-strategi yang dapat menunjang tercapainya tujuan tersebut yang dengan hal ini menggunakan strategi penyuluhan agar dapat terwujud efektif dan efisien.

Sesungguhnya suatu strategi adalah keseluruhan keputusan kondisional tentang tindakan yang akan dijalankan, guna mencapai tujuan. Jadi merumuskan strategi penyuluhan, berarti memperhitungkan kondisi dan situasi (ruang dan waktu) yang dihadapi dan yang akan mungkin dihadapi di masa depan, guna mencapai efektivitas.

Tujuan dari strategi penyuluhan adalah untuk memastikan bahwa terjadi suatu pengertian dalam melakukan penyuluhan, bagaimana cara penerimaan itu terus dibina dengan baik, penggiatan untuk memotivasi, bagaimana mencapai tujuan yang hendak dicapai oleh pihak penyuluh dari proses penyuluhan tersebut. Salah satu satu strategi penyuluhan yang dilakukan oleh PKB adalah dengan menggunakan bahasa lokal (daerah).

Provinsi Sulawesi Tenggara terdiri dari 17 (Tujuh Belas) Kabupaten/Kota dan memiliki bahasa daerah yang berbeda-beda. Berdasarkan keterangan yang diperoleh pada Kantor Bahasa Sulawesi Tenggara, mencatat bahawa bahasa daerah yang ada di Sulawesi Tenggara terbagi atas dua sub rumpun, yakni sub rumpun Bungku-Tolaki dan Sub rumpun Muna-Buton yang masing-masing terdiri atas 4 (empat) dan 6 (enam) bahasa. Untuk bahasa rumpun Bungku-Tolaki tersebut diantaranya, Bahasa Tolaki, Moronene, Kulisusu dan Culambacu. Sedangkan bahasa sub rumpun Muna-Buton terbagi atas bahasa Wakatobi, Muna, Cia-cia, Lasalimu-Kamaru, dan yang paing terbaru ditemukan yakni bahasa Busoa. Berdasarkan data 
Jurnal IImu Komunikasi UHO : Jurnal Penelitian Kajian IImu Komunikasi dan Informasi.

Volume 7, No. 1, Januari 2022, hlm 47-62

pada Bahasa dab Peta Bahasa Indonesia, bahasa yang ada di Provinsi Sulawesi Tenggara adalah sebanyak 14 (Empat Belas) bahasa, yakni bahasa Bajo, Bali, Cia-Cia, Culambacu, Jawa, Kulisusu, Lasalimu-Kamaru, Morunene, Muna, Pulo, Sasak, Sunda, Tolaki dan Wolio.

Bahasa daerah masih sangat aktif digunakan pada beberapa daerah di Provinsi Sulawesi Tenggara, berdasarkan observasi lapangan sementara bahwa dalam melakukan penyuluhan program $\mathrm{KB}$, penyuluh $\mathrm{KB}$ yang masih aktif dalam penggunaan bahasa daerah berada di Kab. Wakatobi, Kab. Konawe dan Kab. Muna. Misalnya saat melakukan seminar atau pertemuan dengan akseptor maupun calon akseptor, penyuluh KB banyak menggunakan bahasa daerah dalam menyampaikan program KB.

Penggunaan bahasa daerah oleh PKB dalam melakukan penyuluhan dimasa pandemi covid-19 dilakukan dengan menggunakan media massa dan tatap muka. Media massa yang digunakan berupa selebaran dalam bentuk poster, penggunaan Facebook dengan melakukan postingan pada beranda dan pengunaan WhasApp (WA) dalam bentuk Group. Berdasarkan hasil observasi, penyuluhan yang dilakukann oleh PKB pada masa pandemi covid-19 dengan menggunakan Bahasa daerah adalah PKB yang ada di Kabupaten Wakatobi dan Kabupaten Konawe yakni melakukan penyuluhan denga menggunakan media massa (selebaran) dengan menggunakan bahasa daerah. Selain itu, PKB dalam melakukan penyuluhan pentingnya menggunakan KB pada masa pandemi covid-19 tidak hanya dengan menggunakan selebaran, facebook dan group WhatsApp (WA), tetapi juga melakukan kunjungan langsung pada calon akseptor dengan tetap memperhatikan protokol kesehatan, bahasa yang digunakan oleh PKB dalam melakukann penyuluhan kadang-kadang menggunakan bahasa daerah, misalnya PKB melakukan komunikasi dengan bahasa daerah dimana sebelumnya mereka sudah saling mengetahui bahasa yang digunakan, karena PKB dan calon akseptor sudah sangat dekat dalam pergaulan sehari-hari sehingga dalam menyampaikan program Keluarga Berencana, PKB tidak mengalami kesulitan. Penyampaian informasi dengan menggunakan bahasa daerah dapat langsung mendapat umpan baliknya, sehingga komunikasi dapat saling mempengaruhi, mendengarkan, menyampaikan pernyataan, keterbukaan, kepekaan antar PKB dan calon akseptor. Berdasarkan hal tersebut maka penulis bertujuan untuk menulis tesis dengan judul Penggunaan Bahasa daerah sebagai strategi Penyuluhan Program Keluarga Berencana pada Kantor Perwakilan Badan Kependudukan dan Keluarga Berencana (BKKBN) Provinsi Sulawesi Tenggara. 
Jurnal IImu Komunikasi UHO : Jurnal Penelitian Kajian IImu Komunikasi dan Informasi.

Volume 7, No. 1, Januari 2022, hlm 47-62

\section{Konsep Komunikasi}

Menurut Lasswell (dalam Mulyana, 2007) cara yang baik menggambarkan komunikasi adalah Dengan menjawab pertanyaan-pertanyaan "Who Says What In Which Channel to Whom With What Effect?" atau siapa mengatakan apa dengan saluran apa kepada siapa dengan pengaruh bagaimana?. Definisi Lasswell ini menyebutkan lima unsur komunikasi yang saling bergantung satu sama lai yakni sumber (komunikator), pesan, saluran atau media, penerima (komunikan), damn efek.

\section{Konsep Media Sosial}

Phillip Kotler dan Kevin Keller (2012) media sosial adalah sarana bagi konsumen untuk berbagi informasi teks, gambar, video dan audio dengan satu sama lain dan dengan perusahaan dan sebaliknya Pemasang iklan tidak harus membayar banyak uang kepada penerbit atau distributor untuk memasang iklannya. Sekarang pemasang iklan dapat membuat konten sendiri yang menarik dan dilihat banyak orang (Zarrella, 2010). Menurut Puntoadi (2011), yaitu pengguna media sosial berfungsi sebagai berikut : (a) Keunggulan membangun personal branding mellui sosial media adalah tidak mengenal trik atau popularitas semu, karena audensilah yang menentukan. (b) Media sosial memberikan sebuah kesempatan yang berfungsi untuk berinteraksi lebih dekat dengan konsumen.

\section{Konsep Penyuluhan}

Penyuluhan kesehatan merupakan kegiatan yang melekat pada setiap upaya peningkatan kesehatan.Penyuluhan kesehatan masyarakat diselenggarakan untuk mengubah perilaku seseorang atau kelompok masyarakat agar hidup sehat melalui komunikasi, informasi, dan edukasi (Richo, 2009). Penyuluhan kesehatan adalah gabungan berbagai kegiatan yang berlandaskan prinsip-prinsip belajar untuk mencapai keadaan, dimana individu, keluarga, kelompok atau masyarakat tahu bagaimana yang harus dilakukan dan apa yang harus dilakukan untuk mencapai kehidupan yang sehat (Effendy, 2010).

\section{Strategi Penyuluhan}

Terdapat beberapa strategi Penyuluhan Kesehatan Masyarakat (PKM) menurut (Kadri, 2014) adalah: (1) Rencana/Program. Pengembangan dari ide dasar, konsep, strategi sampai pada pelaksanaan dalam suatu program penyuluhan, merupakan rangkaian tahapan dalam suatu program komunikasi penyuluhan; (2) Komunikator. Untuk berhasilnya suatu komunikasi penyuluhan, tidak saja ditentukan oleh kemampuan berkomunikasi, tetapi juga oleh diri komunikator (penyuluh) karena fungsi komunikator adalah sebagai pengutaraan pikiran dan perasaannya dalam bentuk pesan untuk membuat komunikan (yang disuluh) 
Jurnal IImu Komunikasi UHO : Jurnal Penelitian Kajian IImu Komunikasi dan Informasi.

Volume 7, No. 1, Januari 2022, hlm 47-62

menjadi tahu, mengubah sikap, pendapat dan perilakunya; (3) Media yang digunakan. Memilih media yang digunakan dalam penyuluhan merupakan keputusan yang sangat penting. Media yang dipilih tentu yang diharapkan adalah media yang benar-benar efektif mencapai sasaran yang dibutuhkan. Pemilihan media hendaklah benar-benar didasarkan pada pertimbangan yang matang karena pilihan yang diambil paling tidak menyangkut masalah biaya, tenaga, dan waktu yang disediakan untuk penyuluhan tersebut; (4) Pesan yang disampaikan. Cara penyampaian pesan di dalam komunikasi penyuluhan merupakan suatu hal dalam menentukan efektivitas program. Penyuluh atau komunikator harus mempertimbangkan tidak hanya isi pesan yang akan disampaikan, tetapi juga bagaimana informasi tersebut disususn untuk dipresentasikan dan apa tipe serta daya tarik pesan yang akan disampaikan.; (5) Sasaran penyuluhan. Sasaran adalah salah satu bagian atau factor penentu keberhasilan suatu komunikasi penyuluhan. Karena bagi penyuluh atau komunikator, patokan berhasilnya upaya penyuluhan adalah apabila pesan-pesan yang disampaikan melalui berbagai saluran dapat sampai pada sasaran dan dimengerti serta ada tanggapan sesuai dengan apa yang dikehendaki oleh komunikator atau penyuluh.

\section{Program Keluarga Berencana}

Konsep keluarga berencana telah banyak dikemukakan para ahli. Menurut Hartanto (2004), Keluarga berencana adalah tindakan yang membantu individu atau pasangan suami istri untuk mendapatkan objek tertentu, yaitu: (1) menghindari kelahiran yang tidak diinginkan, (2) mendapat kelahiran yang diingikan, (3) mengatur interval dintara kehamilan, (4) menentukan jumlah anak dalam keluarga. Mukti (2000) dalam Prabowo dan Anggoro (2020) menyatakan keluarga berencana adalah sebagai upaya ikhtiar untuk memberikan jaminan kesehatan, untuk sang anak maupun ibu, jaminan pendidikan merupakan bekal yang sangat berharga untuk kehidupan kelak dalam masyarakat, untuk memenuhi kesejahtraan dan kemakmuran keluarga lahir dan batin.

\section{Pengertian Bahasa Daerah}

Bahasa daerah berfungsi: lambang kebanggaan daerah, lambang identitas daerah, Sarana perhubungan di dalam keluarga dan masyarakat daerah, sarana pengembangan serta pendukug kebudayaan daerah, bahasa daerah dapat digunakan sebagai bahasa pengantar dalam tahap awal pendidikan apabila diperlukan dalam penyampaian pengetahuan dan/atau keterampilan tertentu. (Manan, 1999). Adapun Kedudukan bahasa daerah yaitu: penunjang bahasa nasional, sumber bahan pengembanagan bahasa nasional, bahasa pengantar pada tingkat permulaan di sekolah dasar di daerah tertentu untuk memperlancar pengajaran bahasa 
Jurnal IImu Komunikasi UHO : Jurnal Penelitian Kajian IImu Komunikasi dan Informasi.

Volume 7, No. 1, Januari 2022, hlm 47-62

Indonesia dan mata pelajaran lain. Jadi, bahasa-bahasa daerah ini secara sosial politik merupakan bahasa kedua (Astuti, 2016).

\section{Teori Difusi Inovasi}

Difusi Inovasi terdiri dari dua padanan kata yaitu difusi dan inovasi. Rogers 1995 dalam Sciffman dan Kanuk (2010) mendefinisikan difusi sebagai (the process by which an innovation is communicated through certain channels overtime among the members of a sosial system), proses dimana suatu inovasi dikomunikasikan melalui saluran tertentu dalam jangka waktu tertentu di antara para anggota suatu sistem sosial disamping itu, difusi juga dapat dianggap sebagai suatu jenis perubahan sosial yaitu suatu proses perubahan yang terjadi dalam struktur dan fungsi sistem sosial.

Menurut Rogers 1995 dalam Sciffman dan Kanuk (2010), bahwa proses difusi inovasi terdapat empat elemen pokok, yaitu: suatu inovasi, dikomunikasikan melalui saluran komunikasi tertentu, dalam jangka waktu dan terjadi diantara anggota-anggota suatu sistem sosial. (1) Inovasi adalah gagasan, tindakan atau barang yang dianggap baru oleh seseorang. Dalam hal ini, kebaruan inovasi diukur secara subjektif menurut pandangan individu yang menerimanya; (2) Saluran komunikasi, adalah alat untuk menyampaikan pesan-pesan inovasi dari sumber kepada penerima. Jika komunikasi dimaksudkan untuk memperkenalkan suatu inovasi kepada khalayak yang banyak dan tersebar luas, maka saluran komunikasi yang lebih tepat, cepat dan efisien, adalah media massa. Tetapi jika komunikasi dimaksudkan untuk mengubah sikap atau perilaku penerima secara personal, maka saluran komunikasi yang paling tepat adalah saluran interpersonal.; (3) Jangka waktu, yakni proses keputusan inovasi dari mulai seseorang mengetahui sampai memutuskan untuk menerima atau menolaknya. Pengukuhan terhadap keputusan itu sangat berkaitan dengan dimensi waktu. Paling tidak dimensi waktu terlihat dalam proses pengambilan keputusan inovasi, keinovatifan seseorang relatif lebih awal atau lebih lambat dalam menerima inovasi, dan kecepatan pengadopsian inovasi dalam sistem sosial; (4) Sistem sosial merupakan kumpulan unit yang berbeda secara fungsional dan terikat dalam kerjasama untuk memecahkan masalah dalam rangka mencapai tujuan bersama.

Inovasi adalah sesuatu ide, perilaku, produk, informasi, dan praktekpraktek baru yang belum banyak diketahui, diterima dan digunakan/diterapkan, dilaksanakan oleh sebagian besar warga masyarakat dalam suatu lokalitas tertentu, yang dapat digunakan atau mendorong terjadinya perubahan-perubahan di segala aspek kehidupan masyarakat demi selalu 
Jurnal IImu Komunikasi UHO : Jurnal Penelitian Kajian IImu Komunikasi dan Informasi.

Volume 7, No. 1, Januari 2022, hlm 47-62

terwujudnya perbaikan-perbaikan mutu hidup setiap individu dan seluruh warga masyarakat yang bersangkutan (Mardikanto, 1993).

\section{METODE PENELITIAN}

Lokasi penelitian dilakukan pada Kantor Perwakilan Badan Kependudukan dan Keluarga Berencana Provinsi Sulawesi Tenggara dengan penentuan 2 (dua) Kabupaten yakni Kabupaten Wakatobi dan Kabupaten Konawe. Pemilihan lokasi penelitian dilakukan secara sengaja (purposive sampling) dengan pertimbangan bahwa penggunaan bahasa daerah masih sangat aktif digunakan dalam memberikan penyuluhan program keluarga berencana. Waktu penelitian dilaksanakan pada Bulan September 2020 sampai dengan Bulan Mei Tahun 2021. Pendekatan penelitian ini peneliti menggunakan penelitian deskriptif. Pendekatan penelitian yang akan digunakan dalam penelitian ini adalah kualitatif. Peneliti menggunakan pendekatan kualitatif karena ingin meneliti tentang penggunaan bahasa daerah sebagai media penyuluhan program keluarga berencana. Subjek penelitian adalah Pegawai yang bekerja pada Kantor Perwakilan BKKBN Provinsi Sultra. Dalam penelitian ini yang menjadi informan sebanyak 9 (Sembilan) informan yang terdiri dari, 1 orang Kepala Bidang Advokasi, Pengggerakan dan Informasi (ADPIN), 2 orang Ketua Kelompok Kerja (pokja) Kampung KB, 2 orang Penyuluh Keluarga Berencana (PKB), 2 orang Calon Akseptor dan 2 orang Akseptor. Dalam penelitian ini peneliti menentukan informan dengan menggunakan tehnik purposive sampling. Penelitian ini akan difokuskan pada "Penggunaan Bahasa daerah sebagai strategi Penyuluhan Program Keluarga Berencana pada Kantor Perwakilan Badan Kependudukan dan Keluarga Berencana (BKKBN) Provinsi Sulawesi Tenggara" yang objek utamanya merupakan penggunaan bahasa daerah Jenis data dalam penelitian ini teridiri dari data kualitatif dan data kuantitatif. Sumber data dalam penelitian ini terdiri dari data primer dan data sekunder. Dalam penelitian ini digunakan beberapa prosedur pengumpulan data, diantaranya yaitu: Observasi, Wawancara mendalam dan dokumentasi Dalam penelitian ini, penulis menggunakan model analisis interaktif. Dalam bentuk ini, peneliti tetap melakukan proses reduksi data, sajian data, dan penarikan simpulan dengan verifikasi saat proses pengumpulan data. 
Jurnal IImu Komunikasi UHO : Jurnal Penelitian Kajian IImu Komunikasi dan Informasi.

Volume 7, No. 1, Januari 2022, hlm 47-62

\section{HASIL DAN PEMBAHASAN}

\section{Penggunaan Bahasa Daerah Sebagai Strategi Penyuluhan Program Keluarga Berencana}

Berdasarkan data BKKBN tahun 2020 diantaranya penurunan angka kelahiran total atau TFR (Total Fertility Rate) dari 3,0 menjadi 2,8. Kesadaran keluarga menggunakan alat kontrasepsi turut meningkat. Hal ini terlihat dari data angka pemakaian alat kontrasepsi (Contraceptive Prevalence Rate = CPR) tahun ini yang berkisar $50 \%$ hingga $60 \%$. Komunikasi pembangunan dalam konteks pemberdayaan masyarakat merupakan segala upaya, cara, dan teknik penyampaian gagasan serta keterampilan pembangunan yang berasal dari atau pihak yang memprakarsai pembangunan kepada masyarakat yang menjadi sasaran agar dapat memahami, menerima, dan berpartisipasi aktif dalam pembangunan masyarakat termaksud dalam hal keberlangsungan program KB dalam menekan angka kelahiran dan meningkatkan kualitas hidup dalam keluarga. Berdasarkan wawancara dengan Sub Koordinator Hubungan Antar Lembaga dan Lini Lapangan Perwakilan BKKBN Sulawesi Tenggara, memberikan keerangan sebagai berikut:

"Upaya penyuluh KB dalam mengelolah program dari sisi perencanaan, langkah pertama yang kami lakukan adalah mengidentifikasi lokasi sasaran program. Seperti apa kondisi masyarakat sekitar, tingkat pendidikan dan sosial budaya. Itu hal yang paling urgen yang menjadi dasar kami dalam menentukan kira-kira pendekapan apa yang bisa kita diterima dengan baik oleh masyarakat setempat". (wawancara dengan pada tanggal 2 Januari 2021 )

Langkah-langkah perencanaan dipikirkan dan dilakukan sejak awal guna untuk meminimalisir kegagalan program di lokasi sasaram program. Seperti argument yang diungapkan di atas bahwa pihak BKKBN melakukan identifikasi guna memastikan kondisi sosial budaya masyarakat dan tingkat pendidikan agar langkah-langkah strategis yang mereka lakukan tepat sasaran dan juga berimplikasi positif kepada masyaraka setempat.

Setelah identifikasi lapangan penyuluh KB lalu mendesain pendekatan media yang akan digunakan sebagai strategi dalam menyampaikan program KB kepada masyarakat. Setelah melalui beberapa pertimbangan dengan beberapa penyuluh yang lain, sehingga lahir ide untuk memanfaatkan beberapa media yang ada termaksud facebook, chat WhtasApp maupun poster. Terkait poster ini kemudian dipajang dan disebarkan di lokasi-lokasi strategis yang bisa dijangkau oleh masyarakat setempat, khususnya para pelaku akseptor.

Dalam memanfaatkan poster pun tidak berhenti disitu saja, penyuluh KB kemudian langkah stragetis apa yang bisa mereka lebih mudah dan dekat saat masuk di lokasi. Kemudian lahir sebuah ide cemerlang, bahwa pembuatan konten poster itu dalam narasinya 
Jurnal IImu Komunikasi UHO : Jurnal Penelitian Kajian IImu Komunikasi dan Informasi.

Volume 7, No. 1, Januari 2022, hlm 47-62

untuk menggunakan bahasa daerah. Penggunaan bahasa daerah ini kemudian disesuaikan dengan lokasi tempat PKB bertugas di lapangan. Di kabupaten Wakatobi dan Konawe Konawe misalnya penyuluh KB memanfaatkan group WhtasApp sebagai media interaktif mereka dalam berkomunikasi dengan para calon aksptornya. Sehingga mereka merasa sangat terbantu apalagi di musim pandemi Covid-19 ini tidak memungkin untuk melakukan pertemuan langsung atau tatap muka. Setelah proses perencanaan selesai dan dianggap tuntas maka langkah selanjutnya adalah melakukan upaya pengorganisasian. Langkah ini menurut Pak Iklamin sebagai Sub Koordinator Hubungan Antar Lembaga dan Lini Lapangan Perwakilan BKKBN Sultra lanjutan dari proses perencanaan sebelumnya.

"Ada beberapa hal yang dilakukan oleh PKB dalam proses pengorganisasian yang harus dilakukan ketika berada di lapangan. Pertama, penguasaan wilayah kerja. Penjabaran poin-poin ini meliputi; pengumpulan data keluarga, data penduduk, kematian, kelahiran hingga perkawinan”. (wawancara pada tanggal 2 Januari 2021 )

Bahasa daerah adalah suatu bahasa yang dituturkan di suatu wilayah dalam sebuah negara kebangsaan, apakah itu pada suatu daerah kecil, negara federal atau provinsi, atau daerah yang lebih luas. Keberadaan sebuah bahasa daerah sangat erat dengan eksitensi suku bangsa yang melahirkan dan menggunakan bahasa tersebut. Bahasa menjadi unsur pendukung utama tradisi dan adat istiadat. Bahasa juga menjadi unsur pembentuk sastra, seni, kebudayaan, hingga peradaban sebuah suku bangsa. Bahasa daerah dipergunakan dalam dalam percakapan sehari-hari.

Bahasa daerah diidealkan memiliki sejumlah fungsi, yakni sebagai alat komunikasi intraetnis, sarana menunjukkan keakraban dan sarana menunjukkan identitas daerah dan kebanggan daerah. Penyuluh Keluarga Berencana (PKB) dalam melakukan aktifitasnya diharuskan bisa menjalin keakraban dengan calon akseptor maupun akseptor, salah satunya adalah dengan menggunakan bahasa daerah yang mana bisa dimengerti dan dipahami oleh calon akseptor maupun akseptor. Sebagaimana yang disampaikan oleh salah satu Penyuluh Keluarga Berencana Kabupaten Wakatobi berikut ini:

"Pada saat saya melakukan kunjungan kepada calon akseptor dalam melakukan penyuluhan program KB, bahasa yang saya gunakan adalah bahasa sehari-hari, seperti bahasa daerah kami disini bahasa Wakataobi. Ini saya gunakan karena mayoritas masyarakat menggunakan bahasa daerah dalam keseharainnya, karena selama ini juga kalau saya gunakan Bahasa Indonesia, calon akseptor maupun akseptor kurang memahami dalam menerima informasi tentang Program KB, oleh sebab itu saya gunakan bahasa daerah pada saat saya memberikan penjelasan tentang Program KB, allhamdulillah calon Akseptor maupun Akseptor cepat memahami maksud yang saya sampaikan". (wawancara pada tanggal 5 Januari 2021). 
Jurnal IImu Komunikasi UHO : Jurnal Penelitian Kajian IImu Komunikasi dan Informasi.

Volume 7, No. 1, Januari 2022, hlm 47-62

Pernyataan serupa disampaikan oleh Penyuluh Keluarga Berencana Kabupaten Konawe, dalam kutipan wawancaranya sebagai berikut :

"Setiap saya melakukan penyuluhan KB kepada akseptor ataupun calon akseptor, bahasa yang saya gunakan adalah bahasa daerah Tolaki. Hal ini saya gunakan karena masyarakat disini lebih cepat paham dan cepat mengerti maksud yang saya sampaikan. Pernah juga saya gunakan bahasa Indonesia, tapi kesannya terlalu formal sehingga Akseptor maupun calon akseptor terkesan enggan untuk melakukan diskusi tentang program KB ini, berbeda kalau saya menggunakan bahasa daerah Tolaki. (wawancara pada tanggal 15 Februrari 2021)

Penyuluh KB dalam melakukan penyuluhan program KB kepada calon akseptor berdasarkan hasil wawancara menunjukkan bahwa PKB selalu menggunakan bahasa daerah dalam melakukan penyuluhan, hal ini dilakukan karena masyarakat setempat masih sangat aktif menggunakan bahasa daerah dalam aktifitasnya sehari-hari, keadaan ini sesuai dengan pernyataan Rooger (1983) bahwa dalam proses difusi inovasi salah satu yang perlu diperhatikan adalah suatu program dikomunikasikan melalui saluran komunikasi tertentu. Temuan penelitian bahwa PKB dalam memberikan Penyuluhan menggunakan saluran komunikasi dangan berbahasa daerah.

Program Penyuluhan Keluarga Berencana bisa dikatakan efektif apabila intensitas kepada calon akseptor maupun akseptor sering dilakukan. Intensitas penyuluhan $\mathrm{KB}$ merupakan frekuensi kegiatan Penyuluh KB dalam memberikan informasi tentang program KB. Menurut Rahayu, dkk (2013), kegiatan penyuluhan harus senantiasa dikembangkan sebagai sarana yang dapat digunakan untuk memperbaiki persepsi, pola pikir, dan tindakan seseoarang, termasuk calon akseptor maupun akseptor itu sendiri. Salah satu pengembangan sarana dalam penyuluhan $\mathrm{KB}$ adalah intensitas penyuluhan program KB dengan menggunakan bahasa daerah. Wawancara dengan Ketua Pokja Kampung KB di Kabupaten Wakatobi memberikan pernyataan sebagai berikut:

"Penyuluhan tentang Program KB di daerah kami ini sering dilakukan, kalau sebelum Pandemi Covid-19, bisa 3 sampai 4 kali dalam sebulan. Kemudian waktu Penyuluh memberikan informasi atau materi tentang KB selalu menggunakan bahasa daerah wakatobi. Tetapi setelah adanya Covid-19 ini, Penyuluh KB kalau secara tatap muka langsung hanya 1 kali dalam sebulan terkadang juga tidak pernah, sebagai gantinya Penyuluh KB menyampaikan melalui media sosial dalam hal ini melalui postingan di beranda facebook dan group WhtatsApp. (wawancara pada tanggal 7 Januari 2021).

Pernyataan serupa disampaikan oleh Ketua Pokja Kampung KB di Kabupatan Konawe, sebagaimana dalam kutipan wawancaranya sebagai berikut :

"Program KB di Kabupaten Konawe untuk setiap bulannya sudah diprogramkan 4 kali dalam satu bulan, atau 1 kali dalam seminggu dengan cara mengumpulkan 
masyarakat baik itu akseptor atau yang sudah menggunakan KB maupun calon akseptor, dalam penyampain materinya PKB selalu mengkombinasikan Bahasa Indonesia dan bahasa daerah, keadaan ini dilakukan sebelum adanya Covid-19. Tetapi dengan adanya Covid-19 ini PKB merubah cara penyuluhannya yakni dengan cara melakukan postingan di media sosial, meskipun kadang-kadang ada yang langsung datang dari rumah ke rumah" (wawancara, pada tanggal 19 Februari 2021).

Intensitas penyuluhan penyuluhan merupakan kegiatan yang sangat diharapkan mampu mengubah persepsi, pengetahuan, sikap, dan tingkah laku akseptor maupun calon akseptor dalam mengambil keputusan tentang penggunaan KB. Berdasarkan Hasil wawancara diperoleh keterangan bahwa penyuluhan program KB dilakukan sebanyak tiga sampai empat kali dalam sebulan dengan mengkombinasikan bahasa daerah dan bahasa Indonesia, ini dilakukan saat sebelum Pandemi Covid-19 belangsung. Saat ini dalam masa Pandemi Covid19, penyuluhan masih tetap berlangsung dengan cara mealakukan penyuluhan dengan menggunakan media sosial yakni postingan pada facebook dan group WhatsApp. Hal ini sejalan dengan pendapat Roger, (1983), bahwa kegiatan peningkatan intensitas penyululah merupakan cara yang efektif dalam meningkatkan pengetahuan calon akseptor maupun akseptor itu sendiri, sehingga dengan baiknya pengetahuan seseorang, maka hal itu akan memperbaiki sikapnya terhadap sesuatu.

Penyampaian pesan tentang program Keluarga berencana belum bisa dikatakan efektif secara menyeluruh di Wilayah Kabupaten Wakatobi dan Konawe. Hal tersebut cukup beralasan karena komunikasi dapat efektif apabila pesan diterima, dimengerti dan dapat mengubah perilaku akseptor maupun calon akseptor sebagaimana dimaksud oleh pengirim pesan, yang mana pesan ditindaklanjuti dengan sebuah perbuatan oleh penerima pesan dan tidak ada hambatan untuk hal itu (Hardjana, 2003).

Untuk itu setiap komunikator dalam hal ini Penyuluh KB perlu mengetahui unsur-unsur komunikasi, misalnya sumber pesan, semua peristiwa komunikasi akan melibatkan sumber sebagai pembuat atau pengirim informasi. Dalam komunikasi antarmanusia, misalnya sumber pesan, bisa terdiri dari satu orang, tetapi juga bisa dalam bentuk kelompok misalnya, dalam kelompok kerja kampung KB. Hasil wawancara dengan akseptor di Kabupaten Wakatobi memberikan keterangan sebagai berikut : "Informasi program KB di Kabupaten Wakatobi ini kami dapatkan dari Penyuluh KB, selain itu ada juga dari Ketua Pokja Kampung KB. (wawancara pada tanggal 7 Januari 2021)

Pernyataan serupa disampaikan oleh calon akseptor di Kabupaten Wakatobi, memberikan keterangan sebagai berikut : "Program KB di kampung saya ini, banyak kami 
Jurnal IImu Komunikasi UHO : Jurnal Penelitian Kajian IImu Komunikasi dan Informasi.

Volume 7, No. 1, Januari 2022, hlm 47-62

peroleh dari penyuluh $\mathrm{KB}$, tetapi kadang juga ada informasi yang disampaikan melalui Ketua Kelompok Kerja Kampung KB”.”(wawancara pada tanggal 6 Januari 2021)

Berdasarkan keterangan dari hasi wawancara diperoleh keterangan bahwa pesan tentang Informasi KB disampaikan oleh Penyuluh KB yang dibantu oleh Ketua Kelompok Kerja Kampung KB kemudian dikomunikasi kepada aksepto maupun calon akseptor. Keadaan ini menggambarkan bahwa komunikai yang terjadi berlangsung secara satu tahap dan berlangsung secara dua tahap. Komunikasi satu tahap yang dimaksud adalah pesan yang disampikan oleh penyuluh KB langsung kepada akseptor maupun calon akseptor, sedangkan komunikasi dua tahap berlangsung dari Penyuluh KB kepada Ketua Poja Kampung KB dan diteruskan ke Akseptor maupun calon akseptor. Unsur komunikasi kedua yang perlu diperhatikan adalah pesan, pesan yang dimaksud dalam proses komunikasi adalah sesuatu yang disampaikan pengirim kepada penerima. Pesan dapat disampaikan dengan cara tatap muka atau melalui media komunikasi. Isinya bisa berupa pengetahuan, informasi, nasihat dan anjuran tentang program KB. Informan dengen penyuluh KB di Kabupaten Wakatobi, memberikan keterangan sebagai berikut :

"Sebagai Penyuluh KB, kami kadang terkendala dengan desain pesan yang akan kami berikan kepada calon akseptor maupun akseptor, sehingga kami mencoba untuk memberikan pesan dengan cara menggunakan bahasa daerah. Keadaan ini berlangsung baik secara tatap muka maupun pada media sosial seperti facebook dan Group WhtasApp." (wawancara pada tanggal 5 Januari 2021).

Wawancara selanjutnya kepada penyuluh KB di Kabupaten Konawe, memberikan keterangan sebagai berikut :

"Penyuluh KB dituntut untuk beradaptasi dengan wilayah kerjanya, saya yang bertugas di Kab. Konawe ini, melakukan hal baru dengan cara memberikan pesan dalam hal ini Program KB menggunakan bahasa daerah Tolaki, ini saya lakukan karena saya melihat disini masih sangat aktif masyarakatnya menggunakan bahasa daerah Tolaki” (wawancara pada tanggal 15 Februrari 2021)

Unsur yang ketiga adalah media, media yang dimaksud ialah alat yang digunakan untuk memindahkan pesan dari sumber kepada penerima. Terdapat beberapa pendapat mengenai saluran atau media. Ada yang menilai bahwa media bisa bermacam-macam bentuknya, misalnya dalam komunikasi antarpribadi pancaindera dianggap sebagai media komunikasi. Selain indera manusia, ada juga saluran komunikasi seperti surat, telepon, telegram yang digolongkan sebagai media komunikasi antarpribadi Unsur yang keempat adalah penerima, penerima adalah pihak yang menjadi sasaran pesan yang dikirim oleh sumber. Penerima bisa terdiri dari satu orang atau lebih, bisa dalam bentuk kelompok. Penerima adalah elemen 
Jurnal IImu Komunikasi UHO : Jurnal Penelitian Kajian IImu Komunikasi dan Informasi.

Volume 7, No. 1, Januari 2022, hlm 47-62

penting dalam komunikasi, karena dialah yang menjadi sasaran dari komunikasi. Jika suatu pesan tidak diterima oleh penerima, akan menimbulkan berbagai macam masalah yang seringkali menuntut perubahan, apakah pada sumber, pesan, atau media. Unsur yang kelima adalah pengaruh, pengaruh atau efek adalah perbedaan antara apa yang dipikirkan, dirasakan dan dilakukan oleh penerima sebelum dan sesudah menerima pesan. Pengaruh ini bisa terjadi pada pengetahuan, sikap dan tinglah laku seseorang. Unsur yang keenam adalah tanggapan balik. Ada yang beranggapan bahwa umpan balik sebenarnya adalah salah satu bentuk dari pada pengaruh yang berasal dari penerima.

Efektifitas penyampaian informasi KB di Kabupaten Wakatobi dan Kabupaten Konawe terutama pesan-pesan yang disampaikan oleh Penyuluh KB dan Ketua Pokja Kampung KB yang berjalan secara simultan. Hal ini dapat dikatakan efektif karena terbukti akseptor maupun calon akseptor setelah memperoleh informasi tentang cara-cara berKB yang baik dari kedua sumber pesan tersebut dapat mengalami perubahan dalam menggunakan KB. Jika dihubungkan dengan konsep efektifitas komunikasi memiliki relevansi yang kuat dengan fenomenana yang terjadi pada akseptor dan calon akseptor. Dalam pandangan dan pengertian komunikasi dan efektifitas komunikasi memberikan pemahaman bahwa komunikasi adalah sebuah proses penyampaian pikiran atau informasi dari seseorang kepada orang lain melalui suatu cara tertentu sehingga orang lain mengerti betul apa yang dimaksud oleh penyampai pikiran atau informasi" (Komaruddin, 1994). Komunikasi dapat efektif apabila pesan diterima dan dimengerti sebagaimana dimaksud oleh pengirim pesan, pesan ditindaklanjuti dengan sebuah perbuatan oleh penerima pesan dan tidak ada hambatan untuk hal itu (Hardjana, 2003).

Komunikasi merupakan proses penyampaian informasi antara satu individu dengan individu yang lain, yang diharapkan memiliki kamampuan dan keterampilan yang sama dalam proses komunikasi. Untuk dapat mempengaruhi komunikan secara efektif, penyampaian pesan perlu memperhatikan langkah-langkah: (1) Attention (perhatian). Artinya bahwa pesannya harus dirancang dan disampaikan sedemikian rupa sehingga dapat menumbuhkan perhatian dari komunikan. Misalnya seorang komunikator (penyuluh) memulai dahulu dengan mengajak berbincang bincang secara santai dengan akseptor dan calon akseptor, tersenyum, menanyakan hal-hal yang ringan, dan sebagainya sebagai cara untuk menarik perhatian. (2) Need (kebutuhan), artinya bahwa komunikator kemudian berusaha meyakinkan komunikan bahwa pesan yang disampaikan itu penting bagi komunikan. (3) Satisfaction (pemuasan), dalam hal ini komunikator memberikan 
Jurnal IImu Komunikasi UHO : Jurnal Penelitian Kajian IImu Komunikasi dan Informasi.

Volume 7, No. 1, Januari 2022, hlm 47-62

bukti bahwa yang disampaikan adalah benar. (4) Visualization (visualisasi) komunikator memberikan bukti-bukti lebih konkret sehingga komunikan bisa turut menyaksikan. (5) Action (tindakan), komunikator mendorong agar.

\section{SIMPULAN}

Berdasarkan hasil dan pembahasan dapat ditarik kesimpulan bahwa pemanfaatan bahasa daerah melalui poster dan media sosial sebagai sebuah strategi komunikasi yang digunakan oleh Penyuluh Keluarga Berencana dengan menggunakan pisau analitis dari asumsi teori difusi inovasi sebagai indikatornya maka ditemukan beberapa hal; pertama, pada tahap pengetahuan penggunaan bahasa daerah untuk menanamkan pemahaman pada akseptor maupun calon akseptor tentang program utama dari BKKBN. Kedua, untuk tahap persuasi bagaimana para PKB menujukan sikap yang perubahan terhadap sebuah inovasi, pada tahap ini masyarakat butuh aksi yang lebih dari sekedar poster saja. Makanya strategi dari PKB mengharuskan mereka untuk turun langsung ke masyarakat untuk memberikan pemahaman. 
Jurnal IImu Komunikasi UHO : Jurnal Penelitian Kajian IImu Komunikasi dan Informasi.

Volume 7, No. 1, Januari 2022, hlm 47-62

\section{DAFTAR PUSTAKA}

Astuti Rahman. (2016). Pengaruh Bahasa Daerah Terhadap Hasil Belajar Bahasa Indonesia Peserta Didik Kelas 1 SD Inpres Maki Kecamatan Lamba-Leda Kabupaten Manggarai Timur. Jurnal Pendidikan Dasar Islam Volume 3 Nomor 2 p-ISSN: 2407-2451

Effendy, Onong Uchjana. (2010). Ilmu Komunikasi Teori? dan Praktek. Bandung. PT. Remaja Rosdakarya.

Hafiar, Herman, Tarifu, Kamil, Sudirman, Susilawaty. (2020). Information Literacy And Political Conflict In The Whatsapp Group. University of Nebraska-Lincoln. Library Philoshophy and Practice (e-journal) ISSN 1522-0222.

Hartanto, H., (2004). Keluarga Berencana dan Kontrasepsi, Jakarta: Pustaka Sinar Harapan.

Irfan, Rberto., Tahir, Kasnawi dan Unde Andi A. (2016). Strategi Komunikasi Penyuluhan Program KB Vasektomi untuk Masyarakat Misikin Perkotaan di Makassar. Jurnal Ilmus Sosial dan Ilmu Politik Unhas. Volume 2 ISSN 2460-3848.

Kadri Sitti Murni. (2014). Strategi Penyuluhan Kesehatan Masyarakat dalam Menanggulangi Bahaya Narkoba di Kabupaten Bone. Jurnal Academica Fisip Untad. Volume 06 ISSN 1411-3341.

Kusnadi, Dedi., Sutarjo, M., \& Nuruzzaman. (2013). Strategi Komunikasi Antarpribadi Pada Penyebaran Informasi Keluaraga Berencana Oleh Petugas KB di Kecamatan Talun Cirebon. Jurnal Signal Prodi Ilmu Komunikasi FISIP. Universitas. Swadaya Gunung Jati. Volume 1. EISSN:2580-1090. P-ISSN:2337-4454

Patmawati, Ika Sari. (2016). Sosialisasi Program Keluarga Berencana oleh Pusat Kesehatan Desa dengan Pendekatan Komunikasi Interpersonal di Desa Jemparing Kecamatan Long Ikis Kabupaten Paser. eJournal Ilmu Komunikasi Vol 4 ISSN 0000-0000.

Phillip Kotler dan Kevin Keller (2012). Manajemen pemasaran edisi ketigabelas jilid 1 dan 2 dialihbahasakan oleh Bob Sabran. Jakarta. Erlangga.

Prabowo Wahyu dan Anggoro Okky Bagus. 2020. Implementasi Program Pembangunan Keluarga Berencana Dalam Meningkatkan Kesejahteraan Dan Kualitas Keluarga Di Kecamatan Kranggan, Temanggung. Jurnal Ekonomi, Sosial dan Humaniora. Volume 2 Nomor 4. E-ISSN 2686-5661

Manan, Solihin. (1999). Pengantar Kaidah berbahasa Indonesia Yang Baik dan Benar. Surabaya. IAIN Surabaya.

Mardikanto, Totok. (1993). Penyuluhan Pembangunan Pertanian. Syrakarta. UNS Press.

Mulyana, Deddy. (2005). Ilmu Komunikasi Suatu Pengantar. Bandung. PT Remaja.

Nasution. 2011. Metode Research Penelitian Ilmiah. Jakarta. Bumi Aksara

Puntoadi, Danis. (2011). Menciptakan Penjualan melalui Media Sosial. Jakarta. PT. Elex Komutindo.

Schiffman, L.G., \& Kanuk, L.L. (2010). Consumer Behaviour (10th ed). New Jersey, Pearson Prentice Hall.

Rema, Karyanti S. (2009). Komunikasi Massa Suatu Pengantar. Bandung. Simbiosa Rekatama Media.

Richo, (2009). Undang-Undang Kesehatan dan Praktik Kedokteran. Yogyakarta. Best Publisher.

Watri Nur Ainun, Umran La Ode Muh, Sumule Marsia. (2018). Dominasi Bahasa Daerah dalam Komunikasi Keluarga Beda Suku Tolaki-Bugis (Studi Kasus di Kelurahan Kendari Caddi Kecamatan Kendari). Jurnal Ilmu Komunikasi UHO: Jurnal Penelitian Kajian Ilmu Komunikasi dan Informasi. Vo 3 No. 3. ISSN 2527-9173

Zarella, Dan . 2010. The Social Media Marketing Book. USA. Oreilly Media.. 